\title{
Evaluation of Yield and Yield Components of Two Potato Cultivars in Khorasan Razavi Province of Iran
}

\author{
Setareh Foroghian ${ }^{1 *}$, Mohammad Reza Asgharipour, Mehdi Ghiafeh Davoodi² \\ ${ }^{1}$ Department of Agronomy, Faculty of Agriculture, University of Zabol, Zabol, Iran \\ ${ }^{2}$ Agricultural Engineering Research Department, Khorasan Razavi Agricultural and Natural Resources Research and \\ Education Center, AREEO, Mashhad, Iran \\ *Email: setarehforoghian@yahoo.com; m_asgharipour@uoz.ac.ir; mehdidavoodi@yahoo.com
}

\begin{abstract}
In order to study the yield and yield components of two potato cultivars, an experiment was conducted as a split plot based on a randomized complete block design with three replicates. The experiment was performed in two locations, Jolgeh-Rokh district, and Fariman city, in professional farmers' fields in Khoarasan Razavi province. The main plots consisted of two potato cultivars, Agria and Fontane cultivars (medium maturing), which were identified as the main cultivars used in chips production factories in the Province. Our results showed higher potential of Agria cultivar for production of stems per plant compared to Fontana cultivar. Both stem number and tuber number per plant along with tuber weight and tuber yield were higher in Fariman location than in Jolgeh-Rokh.
\end{abstract}

Keywords: Field management; potato cultivars; tuber yield

\section{INTRODUCTION}

Potato as a tuber crop is globally a significant source of food and ranked third after rice and wheat (IPC, 2016). From China and semi-arid lands of India to highlands of Indonesian islands and ranches in Ukrain, this crop is under cultivation in about 125 countries, however its highest production is still in industrial countries (IPC, 2016). Various vitamins including vitamin C (Gropper and Smith, 2013;), plenty amount of potassium (Drewnowski and Rahm, 2013; Seth et al., 2014) along with other nutrients and necessary proteins, has made potato an important food crop which is providing a grate share in global human energy and carbohydrate requirement. Its consumption is increasing day by day and due to human population increase and higher cost of other food sources, increasing potato production is inevitable (Drewnowski, 2013; McGill et al., 2013). Potato cultivation area in Iran in 1993-94 was about 160210 ha, and reported average yield was about $31.2 \mathrm{t} \mathrm{ha}^{-1}$ (FAO, 2015). Different potato cultivars respond differently to environment.

High crop production across different environments is a privilege for a crop cultivar. Different climate conditions impose very effective conditions on crop growth and development so finding such crop cultivars requires crop cultivars test across different environments (IPC, 2016; National potato research center, 2016). Potato cultivars respond differently to climate in different environments. In other words, various factors including climate and geographical situation would affect potato production (Arsenault et al., 2001; Masarirambi et al., 2012). Therefore, evaluation of different potato cultivars responses in different environments can be effective in final yield enhancement.

Potato is a winter plant and its optimum growth would be obtained when the average monthly temperature of warmest month be about $25^{\circ} \mathrm{C}$. Its optimum temperature for achieving the highest yield is in the range of $15^{\circ} \mathrm{C}$ to $22{ }^{\circ} \mathrm{C}$ with daily average of $21^{\circ} \mathrm{C}$ (Midmore, 1992). Under $30^{\circ} \mathrm{C}$, net assimilation production is getting close to zero and tuber growth stops (Levy and Veilleux, 2007). Cool nights are quite beneficial for carbohydrate accumulation in tubers while soil temperature more than $20^{\circ} \mathrm{C}$ at nights especially during tuber filling period will increase plants maintenance respiration and slow tuber growth (Aien et al., 2011). Comparison of potato photosynthesis and respiration curves indicated the highest growth occurrence at temperature between $17^{\circ} \mathrm{C}$ to $25^{\circ} \mathrm{C}$ (Midmore, 1992). Aien et al. (2011), reported that $20^{\circ} \mathrm{C}$ is the optimum temperature for photosynthesis and $5^{\circ} \mathrm{C}$ 
increase above this temperature would reduce the crop photosynthesis by $25 \%$. Timlin et al. (2006), reported 24 ${ }^{\circ} \mathrm{C}$ as the optimum temperature for net photosynthesis but highest biomass accumulation would occur at $20^{\circ} \mathrm{C}$.

On the other hand, to determine the potato harvest time, various factors including tuber yield and quality, weather conditions, potato price and finally physiological and genetic components of plant cultivar should be considered (Lal and Sud, 2001). All these situations indicate the importance of potato cultivation location, optimum planting date and field management to achieve the highest possible production. Therefore, regional potato experiments are quite vital for evaluation of yield and yield components of potato. Shaykewich (1995) mentioned that by cultivation of potato crop under different climate conditions, phenology and crop growth rate could be better monitored. Gedif and Yigzaw (2014) evaluated the yield of 8 potato genotypes in five different environments in two years. They reported that the lowest yield obtained from Injibara field in first year of experiment while highest yield obtained in same year in Debretabor field. The objective of this study is the evaluation of yield and yield components of two potato cultivars in four advance farmers' field in Khorasan Razavi of Iran.

\section{MATERIALS AND METHODS}

The current study was carried out as a split plot experiment based on a randomized complete block design with three replicates in Jolgeh-Rokh and Fariman regions located in Khorasan Razavi Province, Iran in
2016. The investigated regions have geographical coordinates of $35^{\circ} 19^{\prime} \mathrm{N}, 57^{\circ} 58^{\prime} \mathrm{E}$ and $45^{\circ} 42 \mathrm{~N}, 56^{\circ} 45^{\prime}$ $\mathrm{E}$, respectively. The Jolgeh-Rokh has cold and temperate climate and Fariman region has Mediterranean climate located in the semi-arid region (Figure 1).

The main plots consisted of two Agria and Fontane cultivars (medium maturing), which were identified as the main cultivars used in chips production factories in the Province. These cultivars account for the highest area of potato cultivation in the Province. The sub-plots consisted of four potato fields, two fields located in Fariman region i.e Mahdavi and Shariati, named after the owners and two fields located in Jolgeh-Rokh region i.e. Razaghi and Khazaee (Figure 2).

In each field, one-hectare patches were allocated to the experiment. Planting dates were selected according to potato physiological base temperature $\left(15^{\circ} \mathrm{C}\right)$. So, planting date was determined in each field by installing a thermometer and recording minimum and maximum daily temperature and ensuring the time of occurrence of physiological base temperature. Accordingly planting dates were $17^{\text {th }}$ of June, $22^{\text {nd }}$ of May, $26^{\text {th }}$ of June and $9^{\text {th }}$ of July in Mahdavi, Shariati, Razaghi and Khazaee fields, respectively. In Mahdavi and Shariati fields (located in Fariman region) $75 \mathrm{~cm}$ distance was considered between the rows and tubers were planted $20 \mathrm{~cm}$ apart, whereas in Razaghi and Khazaee fields (located in Jolgeh-Rokh region) there was $150 \mathrm{~cm}$ distance between the rows and $10 \mathrm{~cm}$ within the rows.

The fields were fertilized according to soil analysis results and fertilizer recommendations using both chemical and organic (cattle manure) fertilizers

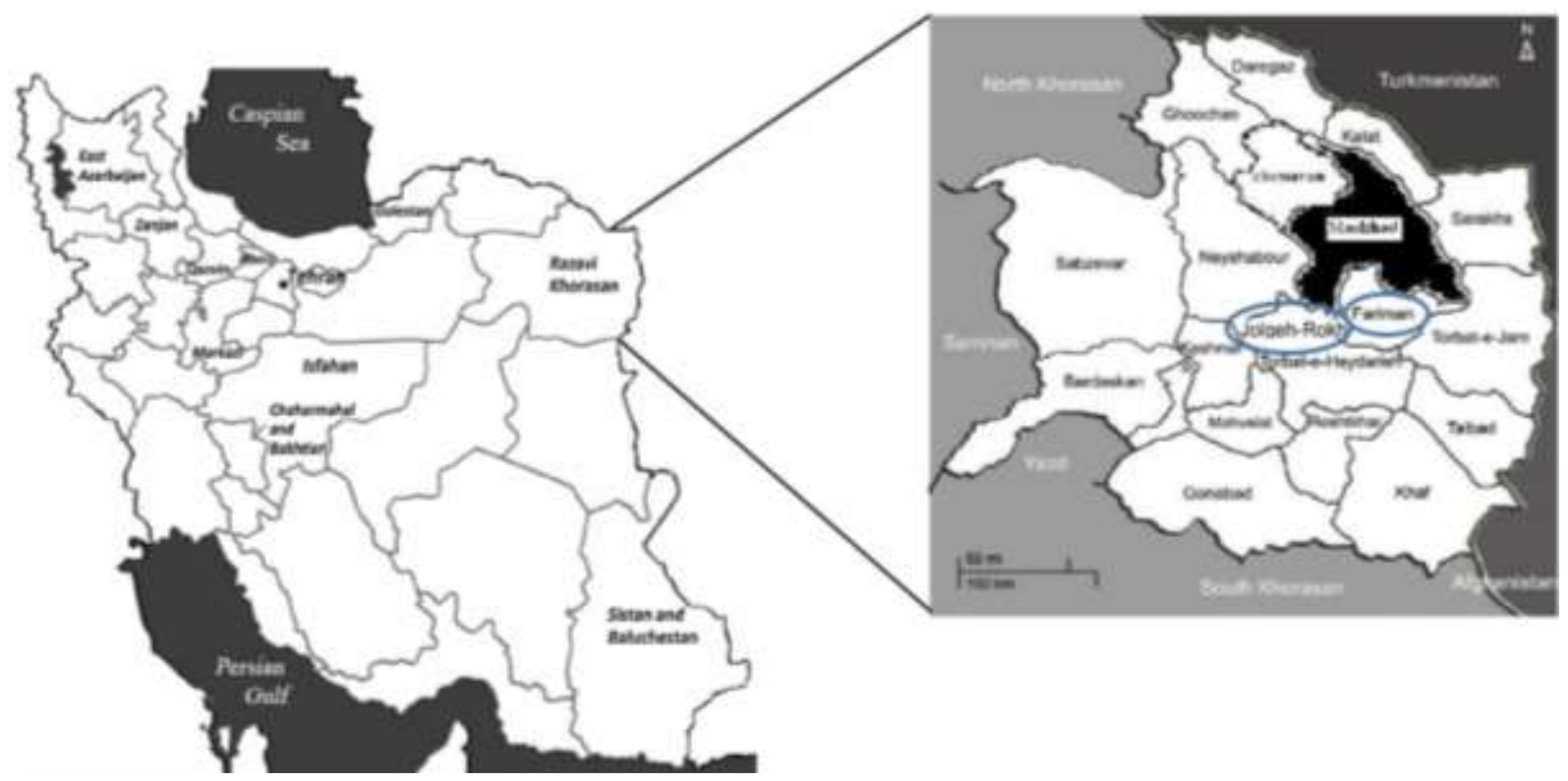

Figure 1: Geolocation of the tested areas 


\begin{tabular}{|c|c|c|c|c|c|c|c|c|}
\hline & \multicolumn{4}{|c|}{ Main Plot (Agria cultivar) } & \multicolumn{4}{|c|}{ Main Plot (Fontane cultivar) } \\
\hline Rep 1 & 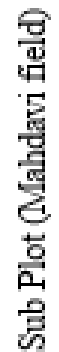 & 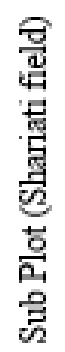 & 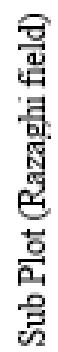 & 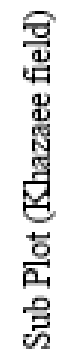 & 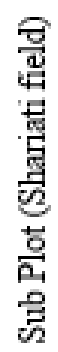 & 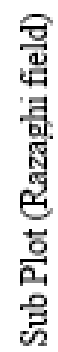 & 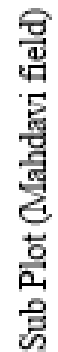 & 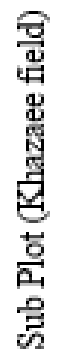 \\
\hline
\end{tabular}

\begin{tabular}{|c|c|c|c|c|c|c|c|c|}
\hline & \multicolumn{4}{|c|}{ Main Plot (Agria cultivar) } & \multicolumn{4}{|c|}{ Main Plot (Fontane cultivar) } \\
\hline Rep 2 & 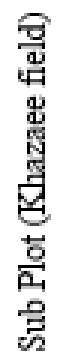 & 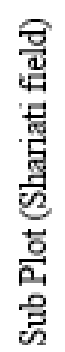 & 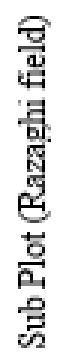 & 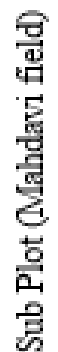 & 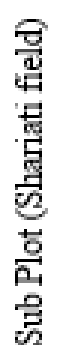 & 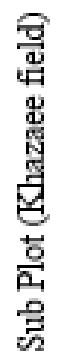 & 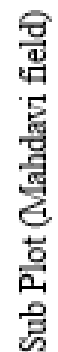 & 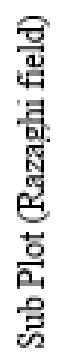 \\
\hline
\end{tabular}

\begin{tabular}{|c|c|c|c|c|c|c|c|c|}
\hline & \multicolumn{4}{|c|}{ Main Plot (Agria cultivar) } & \multicolumn{4}{|c|}{ Main Plot (Fontane cultivar) } \\
\hline Rep 3 & 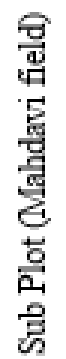 & 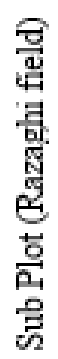 & 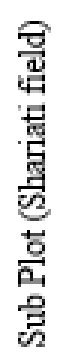 & 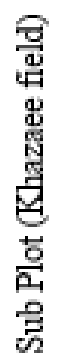 & 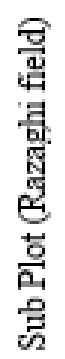 & 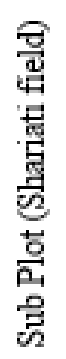 & 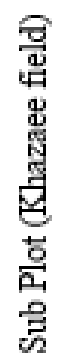 & 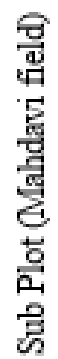 \\
\hline
\end{tabular}

Figure 2: The symbolic shape of split plot design with two main plots, four sub plots and three replicates

(Table 1). Weeds were chemically controlled with Sencor $\left(0.8 \mathrm{~kg} \mathrm{ha}^{-1}\right)$ from tuber planting to seedlings appearance. During the growing season, weeds were also manually removed. According to the soil texture, soil organic matter content and climatic conditions, irrigation schedules were developed as every 6, 8, 6 and 8 days for Mahdavi, Shariati, Razaghi and Khazaee fields, respectively. At the end of the growing season, five plants were randomly selected from each patch and branch number per plant, tuber number per plant and tuber weights were recorded. The final tuber yield was determined after collecting and weighing all the tubers. Harvesting dates were $22^{\text {nd }}$ of October, $22^{\text {nd }}$ of
October, $20^{\text {th }}$ October and $26^{\text {th }}$ of October for Mahdavi, Shariati, Razaghi and Khazaee fields, respectively. All the data were subjected to analysis of variance using the MSTAT-C software. Duncan's multiple range test was used to compare the means at $5 \%$ probability level.

\section{RESULTS AND DISCUSSION}

\section{Stem Number Per Plant}

Cultivars showed a significant effect on stem number per plant (Table 2). Agria cultivar showed $6.99 \%$ more stem per plant in comparison with Fontane 
Table 1. Soil physicochemical properties in four different fields

\begin{tabular}{lllllllllll}
\hline Fields name & Texture & $\begin{array}{l}\text { Silt } \\
(\%)\end{array}$ & $\begin{array}{l}\text { Sand } \\
(\%)\end{array}$ & $\begin{array}{l}\text { Clay } \\
(\%)\end{array}$ & $\mathrm{pH}$ & $\begin{array}{l}\mathrm{EC} \\
(\mathrm{dSm}\end{array}$ & $\begin{array}{l}\text { Carbon }) \\
(\%)\end{array}$ & $\begin{array}{l}\mathrm{N} \\
\left(\mathrm{mgkg}^{-1}\right)\end{array}$ & $\begin{array}{l}\mathrm{P} \\
\left(\mathrm{mgkg}^{-1}\right)\end{array}$ & $\begin{array}{l}\mathrm{K} \\
\left(\mathrm{mgkg}^{-1}\right)\end{array}$ \\
\hline Khazaee & Clay Loam & 34 & 37 & 29 & 7.59 & 2.97 & 0.96 & 462 & 43.4 & 459.4 \\
Razaghi & Clay Loam & 38 & 31 & 31 & 7.46 & 3.48 & 1.11 & 553 & 79.8 & 984 \\
Mahdavi & Loam & 28 & 51 & 21 & 7.8 & 1.89 & 0.66 & 637 & 26.8 & 237.5 \\
Shariati & Clay Loam & 44 & 27 & 29 & 7.37 & 2.76 & 0.94 & 483 & 26 & 284.5 \\
\hline
\end{tabular}

(Figure 3). It seems that Agria has more potential than Fontane for stem per plant production. Lahlou et al. (2003) found significant difference for stem number among all their studied 4 cultivars. Asghari-Zakaria et al. (2007) reported a significant positive correlation between main stem numbers and secondary stem numbers and cultivars which indicated that higher stem number, result in higher yield. Lemaga and Caesar (1990) showed that cultivars with higher number of stem per plant would produce higher tuber yield. This issue was also observed in the results of this study and by increasing the number of stems per plant, the number of tubers also increased (Table 5). However, this trait is a quality trait and separation of environment effect from genotype effect on it, is quite difficult. Environment effect on stem number per plant was also significant (Table 2). In Mahdavi field the number of stem per plant was higher than other fields and generally Fariman region showed more privilege for this trait than Jolgeh-Rokh region. However, Shariati field in Fariman was comparable with Razaghi field in JolgehRokh region (Table 3). It seems that Fariman region with semi-dry climate is more suitable for stem number per plant production than Jolgeh-Rokh region with Mediterranean climate. The reason behind higher stem production in Fariman may be due to high application of animal manure in this location.
Table 3. Main effect of filed on branch number and tuber number per plant

\begin{tabular}{ccc}
\hline Filed & $\begin{array}{c}\text { Branch } \\
\text { number }\end{array}$ & $\begin{array}{c}\text { Tube } \\
\text { number }\end{array}$ \\
\hline Mahdavi & $5.21^{\mathrm{a}}$ & $9.00^{\mathrm{a}}$ \\
Shariati & $5.00^{\mathrm{b}}$ & $8.33^{\mathrm{b}}$ \\
Razaghi & $4.87^{\mathrm{bc}}$ & $7.67^{\mathrm{c}}$ \\
Khazaee & $4.79^{\mathrm{c}}$ & $7.00^{\mathrm{d}}$ \\
\hline
\end{tabular}

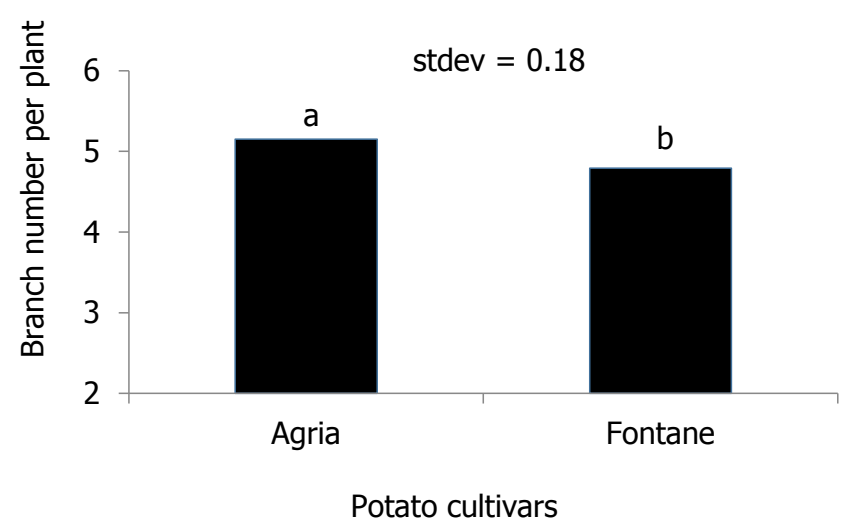

Figure 3. Effect of cultivar on branch number. In each column values with the same letter are not significantly different according to Duncan's multiple range test at $5 \%$ probability level

Table 2. Analysis of variance on yield and yield components of potato as affected by cultivar and filed

\begin{tabular}{cccccc}
\hline $\begin{array}{c}\text { Tuber } \\
\text { yield }\end{array}$ & Tuber weight & $\begin{array}{c}\text { Tuber } \\
\text { number }\end{array}$ & Branch number & df & Sources of variation \\
\hline 5.27 & 16.72 & 1.50 & 0.031 & 2 & Replicate \\
$41.34 *$ & $392.85 *$ & $6.00 \mathrm{~ns}$ & $0.753^{*}$ & 1 & Cultivar \\
1.80 & 22.12 & 0.50 & 0.010 & 2 & Error a \\
$14.21^{* *}$ & $30.95 \mathrm{~ns}$ & $4.44^{* *}$ & $0.197 * *$ & 3 & Field \\
$2.41^{* *}$ & $66.85 * *$ & $0.222 \mathrm{~ns}$ & $0.010 \mathrm{~ns}$ & 3 & Cultivar $\times$ field \\
.188 & 10.717 & 0.167 & 0.017 & 12 & Error b \\
1.08 & 5.05 & 5.10 & 2.65 & - & C.V $(\%)$ \\
\hline
\end{tabular}

$*, * *$ and ns significant at $1 \%, 5 \%$ and no significant, respectively. 
In each column values with the same letter are not significantly different according to Duncan's multiple range test at $5 \%$ probability level.

\section{Tuber Number Per Plant}

There was no significant difference between two cultivars for tuber number per plant (Table 2). However, there are some studies reported differences between potato cultivars for tuber number per plant (Lahlou et al., 2003). In this study both study cultivars showed similar potential for tuber per plant. A significant effect of field location was found on tuber per plant (Table 2), as Mahdavi field showed the highest and Shariati field ranked second. Both Razaghi and Khazaee showed lowest number of tuber per plant. Similar to stem per plant, Fariman region showed higher rank for tuber per plant compared to Jolgeh-Rokh region (Table 3). It seems that Fariman region with semi-dry climate is more suitable for stem number per plant production than Jolgeh-Rokh region with Mediterranean climate. This result may show that there is a positive correlation between stem number per plant with tuber number per plant. Both, Haverkort et al. (1990); Lynch et al. (2001) showed that there is a positive relationship between potato stolon number and tuber number per plant.

\section{Tuber Weight}

Interactive effect of field location and cultivar showed a significant effect of tuber weight (Table 2). Highest tuber weight was obtained by Agria cultivar in Mahdavi and Shariati fields (Table 4). It seems that cultivar Agria compared to Fontane has more potential to produce larger tubers. De la Morena et al. (1994); Ahmadizadeh and Felenji (2011) by comparing yield components of 6 and 22 potato cultivars, respectively, found significant difference between cultivars for tuber weight and reported a high correlation between tuber yield and yield components. Also in the present study, by increasing tuber weight, the tuber yield was increased (Table 5). Many studies have showed that tuber size is an important trait for market and tubers size of more than $55 \mathrm{~mm}$, is more marketable (Shock et al., 1993).

One of important and effective factors on tuber size and weight is planting density. By increasing planting density, due to increase of stem number per plant and thus nutrient stress, higher intra-plant, and space competition, tuber weight would decrease (Kushwah and Singh, 2008; Shakya and Lorenzen, 1993). In this study planting density was 66667 plants/ha and it seems that reduction of population below this value can not only result in same amount of final yield but also provides higher tubers size due to lower interplants competition.
Comparison of different fields indicated that distances of within row of $20 \mathrm{~cm}$ and between rows of $75 \mathrm{~cm}$ in comparison of $10 \mathrm{~cm}$ within row distance and $150 \mathrm{~cm}$ between row distances are more suitable for production of tuber with larger size. Translocation of carbohydrate from shoots to root can be an explanation for higher yields in Fariman region compare to Jolgeh-Rokh.

In general, partitioning of carbohydrates between shoots and roots depends on their demand strength (Zhou and Quebedeaux, 2003; Katoh et al., 2015). During daytime a low part of photosynthetic carbohydrates would be translocated from leaves to underground organs and most of it would be saved in leaf and stem organs which is important for sustaining the photosynthesis during the daytime but at nighttime when there is no photosynthetic production, starch converted again to sugars then would be translocated to tubers and in tubers convert again to starch and saved in amyloplast (Katoh et al., 2015; Braun et al., 2016). Cool weather during tuber filling period is beneficial for translocation of carbohydrates from shoots to tubers. This is because high temperature increases the respiration and reduce transfer of photosynthetic materials to tubers and delay their growth (Katoh et al., 2015; Braun et al., 2016). Based on these facts, Fariman region was more successful to provide such condition in comparison with Jolgeh-Rokh.

Table 4. Interaction between cultivar and fields on tuber weight and final tuber yield

\begin{tabular}{cccc}
\hline Cultivar & Filed & Tuber weight $(\mathrm{g})$ & Tuber yield $\left(\mathrm{kg} \mathrm{ha}^{-1}\right)$ \\
\hline \multirow{3}{*}{ Agria } & Mahdavi & $75.27^{\mathrm{a}}$ & $44.13^{\mathrm{a}}$ \\
& Shariati & $71.63^{\mathrm{a}}$ & $42.43^{\mathrm{b}}$ \\
& Razaghi & $65.57^{\mathrm{b}}$ & $40.03^{\mathrm{c}}$ \\
& Khazaee & $63.03^{\mathrm{b}}$ & $39.60^{\mathrm{cd}}$ \\
\hline \multirow{3}{*}{ Fontane } & Mahdavi & $59.20^{\mathrm{b}}$ & $40.07^{\mathrm{c}}$ \\
& Shariati & $60.60^{\mathrm{b}}$ & $39.20^{\mathrm{d}}$ \\
& Razaghi & $61.97^{\mathrm{b}}$ & $38.80^{\mathrm{d}}$ \\
& Khazaee & $61.37^{\mathrm{b}}$ & $37.63^{\mathrm{e}}$ \\
\hline
\end{tabular}

In each column values with the same letter are not significantly different according to Duncan's multiple range test at $5 \%$ probability level.

\section{Tuber Yield}

Interactive effect of cultivar and field showed significant effect on final tuber yield (Table 2). Highest tuber yield was obtained by planting Agria cultivar in Mahdavi field and lowest yield was for Fontane cultivar in Khazaee field. Agria produced higher yield than Fontane in all 4 fields (Table 4). Considering tuber yield as the multiplication of tuber number by average tuber weight (Lemaga and Caesar, 1990), therefore 
Table 5. Coefficient correlation of studied traits.

\begin{tabular}{lcccc}
\hline & Branch number & Tuber number & Tuber weight & Tuber yield \\
\hline Branch number & 1 & & & \\
Tuber number & $0.722 * *$ & 1 & & \\
Tuber weight & $0.561 * *$ & $0.11^{*}$ & 1 & \\
Tuber yield & $0.769 * *$ & $0.871^{* *}$ & $0.742 * *$ & 1 \\
\hline
\end{tabular}

$*$ and $* *$ significant at $1 \%$ and $5 \%$, respectively.

high yield of Agria in Mahdavi field can be explained by producing high number of tubers and weight. From this perspective, there was a positive correlation between tuber yield and yield components (Table 5).

Furthermore, it seems that optimum environment conditions for suitable planting date, high potential of Agria cultivar to produce high number of tubers along with high tuber weight and finally suitable between and within row distances along with optimum practices like fertilization and pesticides resulted in high yield of Agria in Mahdavi field. Late planting in Khazaee and Razaghi fields compared to Mahdavi field, resulted in shorter plant growing season, and can explain lower yield in these two fields. Gedif, and Yigzaw (2014) in an experiment in Ethiopia evaluated tuber yield of 8 different potato genotypes in 5 different locations across 2 years. They reported that lowest yield was obtained in first year of experiment in Injibara location and highest yield was obtained in same year in Debretabor location. They resulted that among three effective factors including genotype, season and location, the most effective one was location, as $51.51 \%$ in first year and $46.07 \%$ of the second year tuber yield variability across all genotypes were due to location.

\section{CONCLUSION}

In this study Agria compared to Fontane cultivar produced more stem per plant. All fields in Fariman produced more stem and tuber per plant than JolgehRokh. Agria cultivar in both Mahdavi and Shariati fields produced the highest tuber weight and yield. It seems that Agria cultivar compared to Fontane cultivar has more potential for tuber production and it is more probable to produce higher potato yield in Mahdavi and Shariati fields in Fariman location than Razaghi and Khazaee fields in Jolgeh-Rokh.

\section{CONFLICT OF INTEREST}

All authors declare do not have any conflicts of interest between authors and the founder.

\section{REFERENCES}

Ahmadizadeh, M. and Felenji, H. (2011). Evaluating Diversity among Potato Cultivars Using Agro-Morphological and Yield Components in Fall Cultivation of Jiroft Area. American-Eurasian J. Agric. \& Environ. Sci, 11 (5): 655662.

Aien, A., Khetarpal, S. and Pal, M. (2011). Photosynthetic Characteristics of Potato Cultivars Grown under High Temperature. American-Eurasian J. Agric. \& Environ. Sci, 11(5): 633-639.

Arsenault, W. J., LeBlanc, D. A., Tai, G. C. C. and Boswall, P. (2001). Effects of nitrogen application and seed piece spacing on yield and tuber size distribution in eight potato cultivars. American J. Potato Res, 78: 301-309. https://doi.org/10.1007/BF02875695

Asghari-Zakaria, R., Fathi, M. and Hasan-Panah, D. (2007). Sequential Path Analysis of Yield Components in Potato. Potato Research, 49: 273-279. https://doi.org/10.1007/ s11540-007-9022-9

Braun, H., Fontes, P. C. R., da Silva, P. T., Finger, F. L., Cecon, P. R. and Ferreira, A. P. S. (2016). Carbohydrates concentration in leaves of potato plants affected by nitrogen fertilization rates. Rev. Ceres, Viçosa, 63(2): 241-248. http://dx.doi.org/10.1590/0034$737 X 21663020016$

De la Morena, I., Guillen, A. and Garcia del Moral, L. F. (1994). Yield development in potatoes as influenced by cultivar and the timing and level of nitrogen fertilization. American Potato Journal, 71: 165-173. https://doi. org/10.1007/BF02849051

Drewnowski, A. (2013). New metrics of affordable nutrition: which vegetables provide most nutrients for least cost? J. Acad. Nutr. Diet, 113: 1182-7. https://doi.org/10.1016/j. jand.2013.03.015

Drewnowski, A. and Rehm, C. D. (2013). Vegetable cost metrics show that potatoes and beans provide most nutrients per penny. PLoS One, 8(5): 1-7. https://doi. org/10.1371/journal.pone.0063277

FAO. (2015). FAO statistical databases. Available online at http://www.fao.org 
Mulugeta, G., Dessalegn, Y. (2014). Genotype by Environment Interaction Analysis for Tuber Yield of Potato (Solanum tuberosum L.) using a GGE Biplot Method in Amhara Region, Ethiopia. Agricultural Sciences, 5: 239-249. https://doi.org/10.4236/as.2014.54027

Gropper, S. S. and Smith, J. L. (2013). Advanced Nutrition and Human Metabolism 6th Ed. Belmont, CA. (pp. 316). Wadsworth Publishers.

Haverkort, A. J., van de Waart, M. and Bodlaender, K. B. A. (1990). Inter-relationships of the number of initial sprouts, stems, stolons and tubers per potato plant. Potato Research, 33: 269-274. https://doi.org/10.1007/ BF02358456

International Potato Center (IPC). (2016). Potato facts and figures. http://cipotato.org/potato/facts/ Accessed July 21, 2016.

Katoh, A., Ashida, H., Kasajima, I., Shigeoka, S. and Yokota, A. (2015). Potato yield enhancement through intensification of sink and source performances. Breeding Science, 65: 77-84. https://doi.org/10.1270/jsbbs.65.77

Kushwah, V. S. and Singh, S. P. (2008). Effect of intra-row spacing and date of haulm cutting on production of small size tubers. Potato Journal, 35(1-2): 88-90.

Lahlou, O., Ouattar, S. and Ledent, J. F. (2003). The effect of drought and cultivar on growth parameters, yield and yield components of potato. Agronomie, 23: 257-268. https://doi.org/10.1051/agro:2002089

Lal, S. S. and Sud, K. C. (2001). Potato (pp. 497-516). In: Rathore, P.S. (ed.). Techniques and Management of Field Crop Production. Agrobios, India.

Lemaga, B. and Caesar, K. (1990). Relationships between numbers of main stems and yield components of potato as influenced by different day lengths. Potato Research, 33: 257-267. https://doi.org/10.1007/BF02358455

Levy, D. and Veilleux, R. (2007). Adaptation of potato to high temperature and salinity - a review. American Journal of Potato Research, 84(6): 486-506. https://doi. org/10.1007/BF02987885

Lynch, D. R., Kouzob, G. C. and Kawchuk, L. M. (2001). The relationship between yield, main stem number and tuber number in five main crop and two early-maturing cultivars. American Journal of Potato Research, 78: 8390. https://doi.org/10.1007/BF02874763
Masarirambi, M. T., Mandisodza, F., Mashingaidze, A. B. and Bhebhe, E. (2012). Influence of Plant Population and Seed Tuber Size on Growth and Yield Components of Potato (Solanum tuberosum). Int. J. Agric. Biol, 14: 545-549.

McGill, C. R., Kurilich, A. C. and Davignon, J. (2013). The role of potatoes and potato components in cardio metabolic health: a review. Ann Med., 45(7): 467-73. https://doi. org/10.3109/07853890.2013.813633

Midmore, D. J. (1992). Potato production in the tropics (pp. 728-793). In: Harris, P.M. (ed.) Potato crop. London: Chapman and Hall.

National Potato Council (NPC). (2016). Potato facts. http:// www.nationalpotatocouncil.org/potato-facts/ Accessed July 21, 2016.

Seth, A., Mossavar-Rahmani, Y., Kamensky, V., Silver, B., Lakshminarayan, K., Prentice, R. and Van Horn, L., Wassertheil-Smoller, S. (2014). Potassium Intake and Risk of Stroke in Women with Hypertension and Non-hypertension in the Women's Health Initiative. Stroke, 45: 2874-80. https://doi.org/10.1161/ STROKEAHA.114.006046

Shakya, J. D. and Lorenzen, J. H. (1993). Effect of planting density and seed rate on yield and tuber density of common cultivar of Nepal. American Potato Journal, 70: 839.

Shaykewich, C. F. (1995). An appraisal of cereal crop phenology modelling. Can. J. Plant Sci, 75: 329-341. https://doi. org/10.4141/cjps95-057

Shock, C. C., Holmes, Z. A., Stieber, T. D., Eldredga, E. P. and Zhang, P. (1993). The effect of timed water stress on quality, total solids and reducing sugar content of potatoes. American Potato Journal, 70(3): 227-241. https://doi.org/10.1007/BF02849311

Timlin, D., Lutfor Rahman, S. M., Baker, J., Reddy, V. R., Fleisher, D. and Quebedeaux, B. (2006). Whole plant photosynthesis, development and carbon partitioning in potato as a function of temperature. Agron. J, 98: 11951203. https://doi.org/10.2134/agronj2005.0260

Zhou, R., Quebedeaux, B. (2003). Changes in photosynthesis and carbohydrate metabolism in mature apple leaves in response to whole plant source -sink manipulation. J. Amer. Soc. Hort. Sci, 128(1): 113-119. 